Adipose tissue in salivary pleomorphic adenomas is well recognised ${ }^{4}$ although its derivation remains unclear. There are three possible explanations for its presence: first, that it is the result of the incorporation of preexisting stromal fat of the organ in which the tumour has arisen; second, that it represents adipose differentiation of mesenchymal cells in a true biphasic tumour; or, third, that it is caused by adipose metaplasia of primordial myoepithelial cells. While the first possibility might be invoked for pleomorphic adenomas arising in fatty organs such as breast, salivary gland or skin, it seems less likely in the context of the lung where fat is, at best, sparse and which, in this case, was not evident immediately adjacent to the tumour. If one believes, as the weight of evidence tends to suggest, that pleomorphic adenoma "is not a true mixed tumour but is of solely epithelial origin, and that the connective tissue appearances are secondary" then the second postulate seems unsafe. If, as we believe, the third suggestion is true (and the presence of cells (figure, panel B) with the morphological characteristics of lipoblasts ${ }^{6}$ argues that this might be so, absence of myofilaments on electron microscopy notwithstanding) then adipose metaplasia might be added to the list of morphologies ${ }^{3}$ that modified myoepithelial cells can adopt.

Because so few cases of pleomorphic adenoma of the bronchus have been documented it is difficult to assess their prognosis. Undoubted malignant variants have been described ${ }^{178}$ which, in addition to the generally accepted histological features of malignancy, such as necrosis and high mitotic rate, tend to be larger than their benign counterparts. ${ }^{1}$

In the salivary gland pleomorphic adenomas are notorious for their tendency to recur, principally because of their gross morphology and the difficulty in achieving adequate excision in surgically complicated terrain. ${ }^{2}$ Genuine recurrence of a benign pleomorphic adenoma of the bronchus, however, has been recorded only once $^{9}$ and in that instance it is unclear if adequate resection of the primary tumour was achieved. The "recurrence" documented by Sakamoto et $a l^{10}$ is difficult to accept as such, principally because it was found in the periphery of the opposite lung, nine years after initial lobectomy. The possibility that this predominantly chondroid tumour might have represented asynchronous metastases from an undetected low grade mesenchymal tumour elsewhere was not entertained.

It would appear logical, therefore, that benign pleomorphic adenomas of the bronchus should not recur if, as in this case, an adequate resection margin can be obtained.

Our thanks to Mr David Luke for clinical information, to Jan Walker for photographic assistance and to Carol McCormick and Anne Mynes for electron microscopy.

1 Moran CA, Suster S, Askin FB, Koss MN. Benign and malignant salivary gland-type mixed tumors of the lung: clinicopathologic and immunohistochemical study of eigh cases. Cancer 1994;73:2481-90.

2 Huvos AG. Salivary glands. In: Sternberg SS, ed. Diagnostic surgical pathology. 2nd edn. New York: Raven Press, 1994: 813-17.

3 Martinez-Madrigal F, Micheau C. Major salivary glands. In: Sternberg SS, ed. Histology for pathologists. New York: Raven Press, 1992:468.

4 Thackray AC, Lucas RB. Tumors of the major salivary glands. In: Atlas of tumor pathology. 2nd series. Fascicle 10. Washington DC: AFIP, 1974 .

5 Speight PM, Tinkler S. The salivary glands. In: McGee JO'D, Isaacson PG, Wright NA, eds. Oxford textbook of pathology. Vol 2(a). Oxford: Oxford University Press, 1992: 1075.

6 Brooks JJ, Perosio PM. Adipose tissue. In: Sternberg SS, ed. Histology for pathologists. New York: Raven Press, 1992: 56.

7 Spencer H. Bronchial mucous gland tumours. Virchows Arch A Pathol Anat Histopathol 1979;38:101-15.

8 Hayes M, van der Westhuizen N, Forgie R. Malignant mixed tumour of the bronchus: A biphasic neoplasm of epithelial tumour of the bronchus: A biphasic neoplasm of ep

9 Payne W, Schier J, Woolner I. Mixed tumours of the bronchus, salivary gland type. F Thorac Cardiovasc Surg bronchus, salivary

10 Sakamoto H, Uda H, Tanaka T, Oda T, Morino H, Kikui $M$. Pleomorphic adenoma in the periphery of the lung: Report of a case and review of the literature. Arch Pathol Lab Med 1991;115:393-6.
Laboratoire de

Biochimie, Hôpital

Louis-Mourier,

Colombes, France

$\mathrm{J}$ Lamoril

J-C Deybach

Hôpital Saint-Louis, Paris, France: Clinique des Maladies

Infectieuses et

Tropicales

J-M Molina

A de Gouvello

J Modaï

Laboratoire de ParasitologieMycologie

Y J Garin

F Derouin

Correspondence to: Pr F Derouin, Laboratoire de Parasitologie-Mycologie, Hôpital Saint-Louis, 1 avenue Claude Vellefaux, 75010 Paris, France.

75010 Paris, France. 20 July 1995

\section{Detection by PCR of Toxoplasma gondii in blood in the diagnosis of cerebral toxoplasmosis in patients with AIDS}

\author{
J Lamoril, J-M Molina, A de Gouvello, Y J Garin, J-C Deybach, J Modaï, F Derouin
}

\begin{abstract}
The polymerase chain reaction (PCR) for amplification of Toxoplasma gondii DNA was performed prospectively in the blood of 19 patients with AIDS and cerebral toxoplasmosis. The B1 gene and TGR1E sequence were used as targets and results were confirmed by hybridisation. Controls consisted of $24 \mathrm{HIV}$ infected patients with tissue culture proven $T$ gondii para-
\end{abstract}

sitaemia and 57 HIV infected patients without toxoplasmosis. PCR was positive with both targets in 20 of 24 samples (84\%) from patients with parasitaemia. Three of 57 samples (5\%) from patients without toxoplasmosis were PCR positive with either target, but none was positive with both targets. Only three of the 19 patients (16\%) with cerebral toxoplasmosis had a positive PCR with both targets before the 
start of specific treatment. PCR performed in blood is of little diagnostic value in cases of cerebral toxoplasmosis but could be useful in patients with disseminated infection.

(f Clin Pathol 1996;49:89-92)

Keywords: cerebral toxoplasmosis, polymerase chain reaction, AIDS.

The presumptive diagnosis of cerebral toxoplasmosis is based on characteristic neuroradiological abnormalities in patients with serum antibodies to Toxoplasma gondii, and confirmed within approximately two weeks by the clinical and radiological response to specific treatment. An earlier and definitive diagnosis would be highly desirable, however, so that treatment for alternative diagnoses is not delayed. The polymerase chain reaction (PCR) method has been successfully used for such an objective, ${ }^{1-6}$ but its value for the diagnosis of cerebral or disseminated toxoplasmosis in patients with AIDS is still controversial. We report here the results of a PCR study on blood samples from AIDS patients with $T$ gondii infection, using as targets the 35 -fold repetitive $\mathrm{B} 1$ gene $^{6}$ and the repetitive TGR1E sequence. ${ }^{7}$

\section{Methods}

CLINICAL SPECIMENS

We studied prospectively, from September 1992 to March 1994, 19 AIDS patients with cerebral toxoplasmosis. The diagnosis was based on the results of neuroradiology, clinical presentation, presence of anti-toxoplasma antibodies in the serum as determined by enzyme linked immunosorbent assay (ELISA, Platelia IgG, Diagnostics Pasteur), and response to specific treatment. Blood samples were taken before starting specific treatment and then upon treatment for up to $45 \mathrm{~d}$. For each patient, data regarding specific anti-toxoplasma prophylaxis or treatment, CD4 cell count, and detection of anti-toxoplasma antibodies in the serum were recorded.

Stored blood specimens (at $-80^{\circ} \mathrm{C}$ ) from 24 patients with AIDS in whom $T$ gondii parasitaemia had been proven by tissue culture were used as positive controls. Fifty seven samples obtained from $57 \mathrm{HIV}$ infected patients without toxoplasmosis served as negative controls.

\section{PROCEDURES}

Each $10 \mathrm{ml}$ of EDTA blood sample was mixed with an equal volume of sterile $2 \%$ Dextran T 500 (Pharmacia) and sedimented for 15 minutes. The leucocyte-rich supernatant was collected in two tubes and centrifuged at $2000 \times g$ for 10 minutes. One pellet was inoculated into MRC5 tissue cultures ${ }^{8}$; the other was kept at $-80^{\circ} \mathrm{C}$ for PCR. DNA was extracted according to a procedure modified from Loparev et al and then used for PCR. The targets for amplification were the B1 gene $^{6}$ and the TGR1E sequence. ${ }^{7}$ A $131 \mathrm{bp}$ region (position 180 to 309) was amplified with specific primers, B5 (sense) 5'-TGAAGAGAGGAAACAGGTGGTCG (positions 309 to 287) and B6 (antisense): 5'-CCGCCTCCTTCGTCCGTCGTA (positions 180 to $200)$ for the $B 1$ gene, and a $191 \mathrm{bp}$ region (position 28 to 218 ) was amplified with $\mathrm{T} 1$ (sense): 5'-ATGGTCCGGCCGGTGTATGATATGCGAT (positions 28 to 55 ) and T2 (antisense): 5'-TCCCTACGTGGTGCCGCATTGCCT (positions 218 to 194) for the TGR1E sequence. Amplification was carried
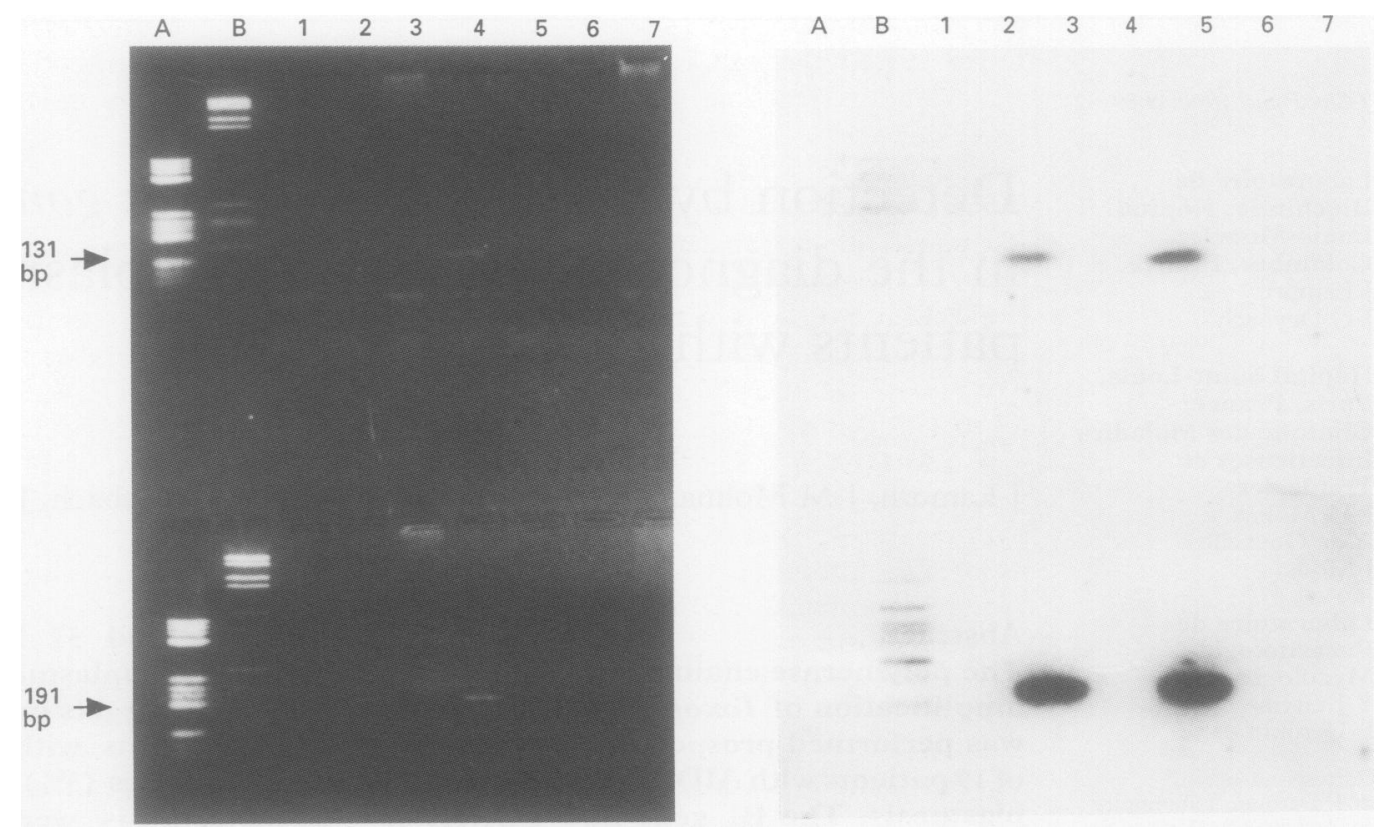

Left panel: Amplified products analysed by electrophoresis through 2\% agarose gels. Lanes $A$ and $B$ are molecular weight markers; lane $B$ molecular weight marker is digoxigenin labelled. Lane 1 is a negative control, lane 2 a positive control, lanes 3, 5, 6, and 7 are negative, lane 4 is positive. 131 bp amplification fragment with the B5/B6 primers and $191 \mathrm{bp}$ amplification fragment with the T1/T2 primers are marked. Right panel: Detection of amplified products after specific hybridisation with digoxigenin labelled oligoprobes. 
Results of the polymerase chain reaction (PCR) in blood of human immunodeficiency virus (HIV) infected patients with or without toxoplasma infection

\begin{tabular}{|c|c|c|c|}
\hline & $\begin{array}{l}\text { Patients with } \\
\text { T gondii parasitaemia } \\
(n=24)\end{array}$ & $\begin{array}{l}\text { Patients without } \\
\text { toxoplasmosis } \\
(n=57)\end{array}$ & $\begin{array}{l}\text { Patients with } \\
\text { cerebral toxoplasmosis } \\
(n=19)\end{array}$ \\
\hline $\begin{array}{l}\text { Presence of serum anti-toxoplasma IgG } \\
\text { Tissue culture proven parasitaemia } \\
\text { Mean CD4 cell count (cells/ml, range) } \\
\text { Specific toxoplasma prophylaxis } \\
\text { Positive PCR with B1 and TGR1E primers } \\
\text { Positive PCR with B1 primers only } \\
\text { Positive PCR with TGR1E primers only } \\
\text { Negative PCR }\end{array}$ & $\begin{array}{l}9 / 10(90 \%)^{\mathrm{a}} \\
24 / 24 \\
\text { NA }^{\mathrm{c}} \\
\text { NA } \\
20(84 \%) \\
0 \\
2(8 \%) \\
2(8 \%)\end{array}$ & $\begin{array}{l}50 / 57(88 \%) \\
0 / 24 \\
50(0-335) \\
35(61 \%) \\
0 \\
2(3 \%) \\
1(2 \%) \\
54(95 \%)\end{array}$ & $\begin{array}{l}18 / 18(100 \%)^{\mathrm{b}} \\
1 / 19(5 \%) \\
56(0-170) \\
7(37 \%) \\
3^{\mathrm{e}}(16 \%) \\
1(5 \%) \\
1(5 \%) \\
14(74 \%)\end{array}$ \\
\hline
\end{tabular}

${ }^{a}$ Results were available for only 10 patients. In two patients, ELISA and agglutination test were negative and only the dye test was positive $(2 \mathrm{IU} / \mathrm{ml})$. One patient was completely negative (ELISA, sensitised agglutination, and dye test).

Not done in one patient.

NA, not available.

d Specific anti-toxoplasma prophylaxis included any of the following drugs alone or in combination: cotrimoxazole, pyrimethamine, dapsone, clindamycin, sulfadiazine.

'Only one patient had positive tissue culture parasitaemia.

out with $20 \mathrm{pmol}$ of each primer in $50 \mathrm{ml}$ of the PCR solution containing 1 unit of Taq DNA polymerase (Beckman), $50 \mathrm{mM} \mathrm{KCl}$, $10 \mathrm{mM}$ Tris- $\mathrm{HCl}\left(\mathrm{pH} 8 \cdot 3\right.$ ), $2.5 \mathrm{mM} \mathrm{MgCl}_{2}$, $200 \mathrm{mM}$ each of dATP, dCTP, and dGTP, and $400 \mathrm{mM}$ dUTP. In order to minimise the risks of contamination, $0.5 \mathrm{U}$ of uracil-DNA-glycosylase (UDG) (Epicentre Technologies) was added. ${ }^{10}$ The reactions were performed in a DNA thermocycler (Hybaid) as follows: two minutes at $50^{\circ} \mathrm{C}$, then 40 cycles of denaturation at $94^{\circ} \mathrm{C}$ for 30 seconds, annealing at $60^{\circ} \mathrm{C}$ for 30 seconds, and elongation at $72^{\circ} \mathrm{C}$ for 30 seconds; then the temperature was maintained at $72^{\circ} \mathrm{C}$ until $50 \mathrm{ml}$ of chloroform was added to prevent any degradation of dU-containing PCR products by residual or reactivated UDG. ${ }^{10}$ Negative controls (desionised water) and positive controls (DNA from $\mathrm{RH}$ tachyzoites) were included in each experiment. PCR inhibitors were sought on negative amplification products by "coamplification" with a known quantity of $T$ gondii DNA; if a negative result was obtained, we concluded that there was an inhibitor of the DNA amplification reaction. Among 148 samples which were found negative by PCR, only two unknown amplification reaction inhibitors were noted $(1 \cdot 4 \%)$.

PCR products were visualised on a $2 \%$ agarose gel stained with ethidium bromide (figure, left panel), then transferred to a nylon membrane Hybond $\mathrm{N}+$ (Amersham). $\mathrm{Hy}-$ bridisation was performed at $60^{\circ} \mathrm{C}$ using digoxigenin labelled oligonucleotides ST1: 5'TACTGGTTGTGTGTCGTTATG (position 87 to 108) for the TGRIE sequence and SB5: 5'-GCAAGAGAAGTATTTGAGGTC (position 249 to 269) for the $\mathrm{B} 1$ gene. Probe target hybrids were detected by chemiluminescence with DIG luminescent detection kit (Boehringer Mannheim) according to the manufacturer's instructions (figure, right panel).

\section{Results}

Twenty of the 24 samples ( $84 \%$ ) from patients with proven parasitaemia were PCR positive with both primers (table). In two other patients, a positive PCR was obtained with TGR1E primers only. The last two patients had negative PCR, with no PCR inhibitors identified. In these two patients, however, the cell pellet consisted of very few cells, and tissue culture showed scarce parasites.

PCR was completely negative in 54/57 patients without toxoplasmosis. Three patients had a positive PCR with either the B1 or TGR1E primers, but none was positive with both. All three patients had a positive serology for toxoplasma and did not receive prophylaxis against toxoplasmosis. The first patient had Pneumocystis carinii pneumonia and 276 CD4 cells $/ \mathrm{ml}$; a second patient had bacterial pneumonia and $335 \mathrm{CD} 4$ cells $/ \mathrm{ml}$; the last patient had disseminated tuberculosis and $8 \mathrm{CD} 4$ cells/ $\mathrm{ml}$, but did not have clinical toxoplasma infection within a year of follow up.

In the prospective study of 19 patients with cerebral toxoplasmosis, cell cultures were negative in 18 patients and PCR was negative in 14 cases, with no evidence of inhibitors of DNA amplification. A positive PCR with either primer alone was noted in two cases. In three patients, PCR was positive with both primers; interestingly, none had received specific antitoxoplasma prophylaxis and one had a tissue culture proven parasitaemia.

During treatment, detection of parasitaemia by tissue culture and by PCR remained negative in all samples.

\section{Discussion}

In this study, we assessed the usefulness of a PCR assay using two repetitive targets for detection of $T$ gondii DNA in blood for the diagnosis of cerebral toxoplasmosis in HIV infected patients. This method was found sensitive to detect $T$ gondii DNA in blood of patients with proven parasitaemia, with $84 \%$ of the samples positive with both targets. These results are consistent with previous studies in HIV infected patients with disseminated toxoplasmosis, where about $80 \%$ of the patients had positive PCR. ${ }^{25}$ Two additional samples were negative with the $\mathrm{B} 1$ primer and positive with TGR1E primers only, possibly in relation to the high repetition of this latter sequence in the parasitic genome. However PCR was completely negative in two cases: the low parasite burden in tissue culture detected with both patients, a failure to extract parasite DNA, or 
storage conditions might explain this discrepancy between PCR and culture.

We then found that all HIV infected patients with no symptoms of cerebral toxoplasmosis had negative PCR with both primers, although most of them were at risk for toxoplasmosis because of their profound immunodeficiency and positive serology for $T$ gondii. A positive PCR with only one primer was occasionally observed in three patients with no signs of toxoplasmosis and a contamination of blood samples cannot be totally excluded, although the usual precautions for PCR were taken and a dUTP-UDG system used. We therefore considered our PCR assay to be positive when positive signals with both primers were obtained.

When used prospectively for diagnosis in patients with symptoms of cerebral toxoplasmosis and no sign of extracerebral involvement, PCR was found to be positive with both primers in only three patients $(16 \%)$ before initiation of treatment. These results are of comparatively much lower sensitivity than those reported by Dupouy-Camet et al using the $\mathrm{B} 1$ gene, where eight of 14 patients where found to be PCR positive. ${ }^{2}$ Such a discrepancy may be explained by the different conditions under which the PCR was carried out and interpreted. In the latter study, a PCR was considered positive when at least two of three repeated PCR tests performed on each sample with one primer were positive, thus exposing the possibility of a false positive result if only one PCR test is performed. In our study we chose to perform PCR with two primers, and a positive result with both primers was required for a positive PCR assay. Our results, however, are more in agreement with those of El Sayed Khalifa et $a l^{5}{ }^{5}$ where only two of 15 patients with AIDS and cerebral toxoplasmosis (13.3\%) had parasitaemia detected by PCR. This low sensitivity of PCR could be explained in part by the prescription of specific prophylaxis, as our three patients with positive PCR did not receive such prophylaxis, whereas PCR was negative in all patients with cerebral toxoplasmosis who received specific prophylaxis.
However, only $37 \%$ of our patients with cerebral toxoplasmosis had prophylaxis, and the sensitivity of PCR in patients without prophylaxis would be only mildly higher $(25 \%)$. A more likely hypothesis is that patients presenting only neurological symptoms of cerebral toxoplasmosis experienced a local reactivation, which was not associated with an haematological spread of the parasite

In conclusion we feel that the detection of $T$ gondii in blood by PCR has a low sensitivity for the diagnosis of cerebral toxoplasmosis in patients with AIDS and is therefore of little value in the clinical situation, although it may be an alternative to tissue culture for the diagnosis of disseminated infections.

We thank Pr J-M Decazes and Dr Y Welker for referring their patients for this study, and $\mathrm{Dr} \mathrm{Ph}$ Thulliez (Institut de Puériculture, Paris) who performed sensitised agglutination and dye tests. This study was supported in part by grants from the Centre d'Etude et de Recherche en Infectiologie, SIDA Urgence, Fonds Banque Nationale de Paris de la Fondation pour la Recherche Médicale, and Université de Paris VII, SaintLouis-Lariboisière.

1 Filice GA, Hitt JA, Mitchell CD, Blackstad M, Sorensen SW. Diagnosis of toxoplasma parasitemia in patients with AIDS by gene detection after amplification with polymerase chain reaction. f Clin Microbiol 1993;31:2327-31.

2 Dupouy-Camet J, Lavareda de Souza L, Maslo C, Paugam A, Saimot AG, Benarous R, et al. Detection of Toxoplasma gondii in venous blood from AIDS patients by polymerase chain reaction. $f$ Clin Microbiol 1993;31:1866-9.

3 Ho-Yen DO, Joss AWL, Balfour AH, Smyth ETM, Baird $\mathrm{D}$, Chatterton JMW. Use of the polymerase chain reaction to detect Toxoplasma gondii in human blood samples. $\mathcal{F}$ to detect Toxoplasma gondin

4 Johnson JD, Butcher PD, Savva D, Holliman RE. Application of the polymerase chain reaction to the diagnosis of human toxoplasmosis. F Infect 1993;26:147-58.

5 El Sayed Khalifa K, Roth A, Roth B, Araseth KN, Janitschke $K$. Value of PCR for evaluating occurrence of parasitemia in immunocompromised patients with cerebral and extracerebral toxoplasmosis. F Clin Microbiol 1994;32:2813-9.

6 Burg JL, Grover CM, Pouletty P, Boothroyd JC. Direct and sensitive detection of a pathogenic protozoon, Toxoplasma gondii, by polymerase chain reaction. $\mathcal{f}$ Clin Microbiol 1989;27:1787-92.

7 Cristina N, Liaud MF, Santoro F, Oury B, AmbroiseThomas P. A family of repeated DNA sequences in Toxoplasma gondii: cloning, sequence analysis, and use in plasma gondii: cloning, sequence analysis, and use
strain characterization. Exp Parasitol 1991;73:73-81.

8 Derouin F, Sarfati C, Beauvais B, Iliou MC, Dehen L, Larivière $\mathrm{M}$. Laboratory diagnosis of pulmonary toxoLariviere $M$. Laboratory diagnosis of pulmonary toxo-
plasmosis in patients with acquired immunodeficiency syndrome. f Clin Microbiol 1989;27:1661-3.

9 Loparev VN, Cartas MA, Monken CE, Velpandi CE, A Srinivasan. An efficient and simple method of DNA extraction from whole blood and cell lines to identify infectious agents. $\mathcal{F}$ Virol Methods 1991;34:105-12.

10 Longo MC, Berninger MS, Hartley JL. Use of uracile-Nglycosylase to control carry-over contamination in polymerase chain reaction. Gene 1990;93:125-8. 